Tanjungpura Law Journal, Vol. 4, Issue 2, July 2020: 161 - 177

ISSN Print: 2541-0482 | ISSN Online: 2541-0490

Open Access at: http://jurnal.untan.ac.id/index.php/tlj

Article Info

Submitted: 21 Mei 2020 | Reviewed: 20 Juni 2020 | Accepted: 12 Juli 2020

\title{
PERLINDUNGAN DAN PELESTARIAN LINGKUNGAN LAUT MENURUT HUKUM INTERNASIONAL
}

\author{
Dewa Gede Sudika Mangku1
}

\begin{abstract}
Issues relating to the protection of the marine environtment are of concern, including by international law. This research discusses the prtection and preservation of the marine environment according to international law. This research is a normative legal research. The approach used is the statutory approach. The research results show that the protection and preservation of the marine environment receives serious attention by international law, especially through regulation through the 1982 Nations Convention on the Law of the Sea (UNCLOS) which fully regulates the protection and preservation of the marine environment in a Chapter, namely Chapter XII which consists of 45 articles (192-237). In this Chapter there are several important aspects relating to the protection and preservation of the marine environment, namely the existence of general obligations of countries in terms of protecting the marine environment (Articles 192-160), obligations of the state in terms of pollution (Articles 194-196), global cooperation and in the framework of protecting the marine environment (Articles 197201), technical assistance (Articles 202-203), environmental monitoring and analysis (Articles 204-206), making laws and regulations and accompanying law enforcement (Articles 207-234), responsibilities and compensation obligations (Article 235), immunity rights (Article 236), obligations under other conventions concerning the protection of the marine environment (Article 237).
\end{abstract}

Keywords: international law, legal protection, marine environment, UNCLOS 1982

\begin{abstract}
Abstrak
Persoalan berkaitan perlindungan lingkungan laut menjadi perhatian, termasuk oleh hukum internasional. Penelitian ini membahas perlindungan dan pelestarian lingkungan laut menurut hukum internasional. Penelitian ini adalah penelitian hukum normatif. Pendekatan yang digunakan adalah pendekatan perundangan-undangan. Dari hasil penelitian didapatkan hasil bahwa perlindungan dan pelestarian lingkungan laut mendapatkan perhatian serius oleh hukum internasional, terutama melalui pengaturan melalui Nations Convention on The Law of the Sea (UNCLOS) 1982 yang secara lengkap mengatur mengenai perlindungan dan pelestarian lingkungan laut dalam suatu Bab, yaitu Bab XII yang terdiri atas 45 pasal (192-237). Dalam Bab tersebut terdapat beberapa aspek penting yang berkaitan dengan perlindungan dan pelestarian lingkungan laut, yaitu adanya kewajiban umum negara-negara dalam hal perlindungan lingkungan laut (Pasal 192- 193), kewajiban negara dalam hal pencemaran (Pasal 194-196), kerjasama global dan regional dalam rangka perlindungan lingkungan laut (Pasal 197- 201), bantuan teknik (Pasal 202-203), monitoring dan analisa lingkungan (Pasal 204-206), pembuatan peraturan perundang-undang disertai penegakan hukumnya (Pasal 207-234), tanggung jawab dan kewajiban ganti rugi (Pasal 235), hak kekebalan (Pasal 236), kewajibankewajiban berdasarkan konvensi lain mengenai perlindungan lingkungan laut (Pasal 237).
\end{abstract}

Kata Kunci: hukum internasional, lingkungan laut, perlindungan hukum, UNCLOS 1982

1 Jurusan Hukum dan Kewarganegaraan Universitas Pendidikan Ganesha, email: 


\section{Pendahuluan}

Laut memiliki manfaat dan peranan besar bagi kehidupan manusia yang juga merupakan bagian dari lingkungan hidup. Seiring dengan berkembangnya ilmu pengetahuan dan teknologi, fungsi laut bertambah dengan ditemukannya berbagai macam bahan tambang dan galian yang berharga. ${ }^{2}$ Laut mempunyai sifat istimewa bagi kehidupan manusia, begitu pula hukum laut. Hukum pada umumnya adalah rangkaian peraturanperaturan mengenai tingkah laku orangorang sebagai anggota masyarakat itu. Laut adalah suatu keluasan air yang meluas diantara berbagai benua dan pulau-pulau di dunia. ${ }^{3}$

Pembahasan mengenai sejarah hukum laut internasional tentunya akan terkait dengan fungsi-fungsi laut yang telah dirasakan oleh manusia. ${ }^{4}$ Fungsifungsi dari laut memberikan dorongan terhadap penguasaaan dan pemanfaatan laut oleh setiap negara atau kerajaan yang didasarkan atas suatu konsepsi hukum. Lahirnya konsepsi hukum laut internasional tidak dapat dilepaskan dari sejarah pertumbuhan hukum laut

2 Dikdik Mohammad Sodik. 2011. Hukum Laut Internasional dan Pengaturannya di Indonesia. Bandung: Refika Aditama. hlm. 1

3 Wirjono Prodjodikoro. 1984. Hukum Laut Bagi Indonesia.Bandung: Sumur Bandung. hlm. 8

4 Usmawadi Amir. 2013. "Penegakan Hukum IUU Fishing Menurut UNCLOS 1982 (Studi Kasus: Volga Case)". Jurnal Opinio Juris, 12. hlm. 68-92. internasional yang mengenal pertarungan antara dua konsepsi, yakni: ${ }^{5}$

a. Res Communis, yang menyatakan bahwa laut itu adalah milik bersama masyarakat dunia, dan karena itu tidak dapat diambil atau dimiliki oleh masingmasing negara; ${ }^{6}$

b. Res Nulius, yang menyatakan bahwa laut tidak ada yang memiliki dan karena itu dapat diambil dan dimiliki oleh masing-masing negara. ${ }^{7}$

Pertumbuhan dan perkembangan kedua doktrin tersebut diawali dengan sejarah panjang mengenai penguasaan laut oleh Imperium Roma. Imperium Roma menguasai tepi Lautan Tengah dan karenanya menguasai seluruh Lautan Tengah secara mutlak. Dengan demikian, Lautan Tengah bebas dari gangguan bajak laut, sehingga semua orang dapat mempergunakan Lautan Tengah dengan aman dan sejahtera. Pemikiran hukum bangsa Romawi terhadap laut didasarkan atas doktrin res communis, yang memandang penggunaan laut bebas atau terbuka bagi setiap orang. ${ }^{8}$

\footnotetext{
5 N.K. Ningsih, M. Indra \& W. Edorita. 2016. "Pertanggungjawaban Negara Terhadap Pencemaran Laut Timor Oleh Tumpahan Minyak Australia Berdasarkan UNCLOS III 1982 dan Hukum Lingkungan Internasional". Jurnal Online Mahasiswa, 3 (1). hlm. 1-15.

6 Charlotte Ku. 1990. "The Concept of Res Communis in International Law". History of European Ideas, 12 (4). hlm. 459-477.

7 F.S. Ruddy. 1968. "Res Nullius and Occupation in Roman and International Law". University of Missoury (Kansas City) Law Review. 36. hlm. 274282.

8 Mochtar Kusumaatmadja. 1986. Hukum Laut Internasional. Bandung: Binacipta. hlm. 3
} 
Sekitar abad ke-14 hingga 17 terjadi perlombaan bangsa-bangsa barat untuk mengarungi lautan dalam rangka mencari benua-benua baru dan dengan tujuan utama mencari negara atau bangsa yang merupakan asal dari penghasil rempahrempah. Oleh karena itu, timbulah klaim wilayah dari bangsa-bangsa penjelajah terhadap lautan. Salah satu contoh seperti bangsa Romawi yang telah banyak menunjukan tanda-tanda dalam melaksanakan kekuasaannya bahwa laut itu dapat dimiliki melalui hak penduduk pantai untuk menangkap ikan di kawasan laut yang diakuinya. ${ }^{9}$ Dalam kurun waktu yang bersamaan dengan awal penjelajahan belahan bumi ini tentu menambah ramainya pelayaran lintas benua dan samudra, status hukum atas lautan pun mulai dipersoalkan. Spanyol, Portugal, Italia, dan Inggris berpendapat, bahwa lautan itu dapat dimiliki. Di tengah negara-negara yang berlomba-lomba mengklaim kedaulatan atas laut tersebut, Belanda sebagai negara kecil yang juga ikut mengarungi lautan merasa tidak lagi bebas untuk berlayar di Laut Utara maupun Laut Atlantik. Oleh sebab itu, Belanda menentang klaim dari negaranegara tersebut dengan mengatakan bahwa lautan itu tidak boleh dimiliki oleh

\footnotetext{
9 E. R Agoes. 2004. "Praktik Negara-Negara Atas Konsepsi Negara Kepulauan". Indonesian Journal of International Law. 1 (3). hlm. 441-464.
}

siapapun dan harus terbuka bagi semua bangsa. ${ }^{10}$

Negara Indonesia adalah salah satu negara yang diuntungkan dengan disahkan dan diberlakukannya UNCLOS 1982, ini disebabkan karena Indonesia memiliki wilayah laut yang sangat luas dan letak geografis yang unik. ${ }^{11} \mathrm{Di}$ samping letak kepulauan Indonesia yang berada pada garis khatulistiwa, juga posisi geografis ini menurut kenyataannya merupakan negara kepulauan (archipelagic state) yang berada pada posisi silang dunia, yaitu di antara dua benua yakni Benua Asia dan Australia dan di antara dua samudera yaitu Samudera India dan Samudera Pasifik. Luas wilayah laut Indonesia dapat dirinci menjadi 0,3 juta $\mathrm{km}^{2}$ laut teritorial, 2,8 juta $\mathrm{km}^{2}$ perairan nusantara (perairan kepulauan), dan 2,7 juta $\mathrm{km}^{2}$ Zona Ekonomi Eksklusif Indonesia. ${ }^{12}$

Pada wilayah laut inilah terdapat lingkungan laut Indonesia. Pada lingkungan laut Indonesia terdapat berbagai macam sumber kekayaan alam, baik kekayaan alam hayati maupun nonhayati, dan memiliki peranan yang sangat

\footnotetext{
10 Ridwan Lasabuda. 2013. "Pembangunan Wilayah Pesisir dan Lautan dalam Perspektif Negara Kepulauan Republik Indonesia". Jurnal IImiah Platax. 1 (2). hlm. 92-101.

11 A. Soemarmi, E. Indarti, Pujiyono, \& A. Diamantina. 2019. "Konsep Negara Kepulauan dalam Upaya Perlindungan Wilayah Pengelolaan Perikanan Indonesia". Masalah-Masalah Hukum. 48 (3). hlm. 241-248.

12 Hasbullah F. Sjawie. 1999. "Konsep Negara Kepulauan pada Konferensi Hukum Laut Tahun 1958 dan Tahun 1960". Jurnal Hukum dan Pembangunan, 29 (2). hlm. 131-143.
} 
penting, misalnya sebagai sarana penghubung, media rekreasi, jalan raya perdagangan, dan sebagai alat pemersatu bangsa Indonesia. Sejak tahun 1985, Indonesia telah meratifikasi UNCLOS 1982 melalui Undang-Undang Nomor 17 Tahun 1985 tentang Pengesahan UNCLOS 1982.

Pada kenyataannya, permasalahan mengenai hukum laut semakin banyak. Meskipun sudah banyak kebijakan yang dikeluarkan oleh pemerintah, tetapi pada kenyataannya hal tersebut belum mampu mengatasi permasalahan-permasalahan yang ada, termasuk dalam hal perlindungan lingkungan laut. Hal ini dapat dilihat dari kerusakan lingkungan laut Indonesia yang semakin hari semakin meningkat. Tapi ironisnya, masalah kerusakan lingkungan laut yang terjadi di wilayah perairan Indonesia bukanlah hal yang asing lagi, ini bisa dilihat dari berbagai pemberitaan di media massa yang menyorot hal tersebut. Melihat hal ini, nampak bahwa seolah-olah pemerintah lalai menjalankan fungsinya dalam menjaga dan melindungi wilayah laut Indonesia dari kerusakan. Penelitian ini akan membahas bagaimana perlindungan dan pelestarian lingkungan laut dari perspektif hukum internasional.

\section{Metode}

Penelitian ini menggunakan jenis penelitian hukum normatif. I Made Pasek Diantha mengemukakan metode penelitian hukum secara normatif adalah metode yang meneliti aturan hukum pada persepektif iternal yang objek penelitiannya ialah norma hukum. ${ }^{13}$ Pendekatan yang digunakan pada karya ilmiah ini adalah pendekatan perundangan-undangan. Adapun data yang digunakan dalam penelitian adalah data sekunder berupa bahan hukum primer yang terdiri dari peraturan perundang-undangan yang berlaku dan perjanjian-perjanjian internasional. Bahan hukum sekunder yang terdiri dari hasil penelitian, buku-buku teks, jurnal ilmiah, surat kabar, dan berita internet yang relevan dengan permasalahan yang diteliti. Bahan non hukum lainnya seperti kamus hukum, ensiklopedia dan sebagainya. Selanjutnya akan dilakukan analisis secara kualitatif.

\section{Analisis Dan Pembahasan}

\section{A. Sumber Hukum Laut Internasional}

Sumber hukum laut yang paling penting hingga saat adalah kebiasaan internasional. Kebiasaan internasional ini lahir akibat dari perbuatan yang dilakukan secara terus menerus hingga dianggap sebuah kebiasaan umum yang diterima sebagai hukum atas dasar kesamaan kebutuhan di laut. Sebagai sumber hukum internasional, kebiasaan internasional sangat erat kaitannya dengan perjanjian internasional.

\footnotetext{
13 I Made Pasek Diantha. 2017. Metodologi Penelitian Hukum Normatif Dalam Justifikasi Teori Hukum. Jakarta: Prenada Media Group. hIm. 12.
} 
Sumber hukum laut yang sah adalah hasil dari Konferensi PBB tentang hukum laut pada tahun 1958 di Jenewa. Konferensi ini berhasil menyepakati empat konvensi, yaitu: ${ }^{14}$

1) Convention on the Territorial Sea and the Contiguous Zone (Konvensi tentang Laut Teritorial dan Zona Tambahan), mulai berlaku pada tanggal 10 September 1964:15

2) Convention on the High Seas (Konvensi tentang Laut Lepas), mulai berlaku pada tanggal 30 September 1962;16

3) Convention on Fishing and Conservation of the Living Resources of the High Seas (Konvensi tentang perikanan dan Perlindungan Sumber-Sumber Daya Hayati Laut Lepas), mulai berlaku pada tanggal 20 Maret 1966;

4) Convention on the Continental Shelf (Konvensi tentang Landas Kontinen), mulai berlaku pada tanggal 10 Juni $1964 .{ }^{17}$

14 I Wayan Parthiana. 2014. Hukum Laut Internasional dan Hukum Laut Indonesia. Bandung: Yrama Widya. hlm. 17

15 E. Ereli. 1966. "Submerged Lands Act and the Geneva Convention on the Territorial Sea and the Contiguous Zone". Tulane Law Review. 41. hlm. 555.

16 D. Laffoley \& D. Freestone. 2017. "A World of Difference-Opportunities for Applying the 1972 World Heritage Convention to the High Seas". Aquatic Conservation: Marine and Freshwater Ecosystems, 27, hlm. 78-88.

17 T. L. McDorman. 2012. "The Continental Shelf Regime in the Law of the Sea Convention: A Reflection on the First Thirty Years". The International Journal of Marine and Coastal Law. 27 (4). hlm. 743-751.
Konferensi PBB yang dilaksanakan di New York dan Jenewa juga melahirkan kesepakatan Konvensi Hukum Laut PBB atau United Nations Convention on the Law of the Sea (UNCLOS) pada tahun 1982 juga dapat dikatakan sebagai sumber hukum laut internasional. Konvensi ini mengatur tentang ketentuan kelautan secara utuh dan terpadu sebagai satu kesatuan.

\section{B. Pencemaran Lingkungan Laut dalam Hukum Internasional}

Instrumen hukum utama dalam konteks perlindungan lingkungan laut ialah "United Nations Convention on The Law of the Sea (UNCLOS) 1982. UNCLOS 1982 menyatakan pengertian pencemaran yaitu: "Dimasukkannya bahan atau energi oleh manusia secara langsung atau tidak langsung ke dalam lingkungan laut yang membawa akibat buruk sedemikian rupa seperti kerusakan pada kekayaan hati dan kehidupan di laut, bahaya bagi kesehatan manusia, gangguan terhadap kegiatan di laut termasuk penangkapan ikan dan penggunaan laut yang sah lainnya, penurunan kualitas kegunaan air laut dan mengurangi kenyamanan".

UNCLOS telah mengkombinasikan batasan-batasan terhadap pencemaran laut lebih luas serta menyebutkan sumber pencemaran dari segala aspek, seperti dari land based activites (aktivitas darat), seabed activities (aktivitas lepas pantai), activites in the area (aktivitas di dasar samudera), 
dumping (pembuangan limbah), vessels (kapal), maupun dari udara (atmosfer). UNCLOS 1982 mengatur perlindungan lingkungan laut dan pelestarian lingkungan laut dalam Bab XII yang terdiri dari Pasal 192 - Pasal 237. ${ }^{18}$

Suatu tindakan untuk mencegah dan mengendalikan pencemaran lingkungan laut yang disebabkan oleh segala sumber diharuskan sesuai dengan ketentuan yang ada dalam Konvensi Perserikatan BangsaBangsa tentang Hukum Laut 1982 (UNCLOS) (Undang-Undang Nomor 17 Tahun 1985 tentang Pengesahan Konvensi Hukum Laut 1982). Baik secara individu maupun secara bersama-sama untuk mencegah, mengurangi dan mengendalikan pencemaran lingkungan laut yang dibebabkan oleh segala sumber (UNCLOS 1982, Pasal 194 angka 1). Setiap negara harus mengambil tindakan yang diperlukan untuk menjamin agar kegiatan-kegiatan yang berada di bawah yurisdiksi atau pengawasan mereka dilakukan dengan sedemikian rupa supaya tindakan-tindakan tersebut tidak mengakibatkan kerusakan yang disebabkan oleh pencemaran yang dilakukan oleh negara lain dan lingkungannya, dan agar pencemaran yang timbul dari tindakan-tindakan dan kegiatan di bawah yurisdiksi atau pengawasan mereka tidak menyebar

18 Nadia Nurani Isfarin. 2012. "Perlindungan Lingkungan Laut Selat Malaka Dari Pencemaran Minyak Lintas Batas". Jurnal IImu Hukum. 15 (2). hlm. 206-224. melewati daerah-daerah yang ada di bawah pelaksanaan hak-hak kedaulatannya (UNCLOS 1982, Pasal 194 angka 2). ${ }^{19}$

Klasifikasi pencemaran laut menurut UNCLOS 1982, sebagaimana terdapat dalam Bagian 5 mengenai PeraturanPeraturan Internasional dan PerundangUndangan Nasional Untuk Mencegah dan Mengurangi dan Mengendalikan Pencemaran Lingkungan Laut (International Rules and National Legislation to Prevent, Reduce, and Control Pollution of the Marine Environment) yakni::20

a. Pencemaran laut yang berasal dari sumber daratan (UNCLOS 1982, Pasal 207)

b. Pencemaran laut yang berasal dari kegiatan dasar laut yang tunduk pada yurisdiksi nasional (UNCLOS 1982, Pasal 208)

c. Pencemaran laut yang berasal dari kegiatan-kegiatan di kawasan (UNCLOS 1982, Pasal 209)

d. Pencemaran laut karena dumping (UNCLOS 1982, Pasal 210)

e. Pencemaran laut yang berasal dari kendaraan air (UNCLOS 1982, Pasal 211)

\footnotetext{
19 Nong Hong. 2012. UNCLOS and Ocean Dispute Settlement: Law and Politics in the South China Sea. London \& New York: Routledge.

20 Ahmad Sofyan. 2010. "Tanggung Jawab dalam Pencemaran Laut yang Disebabkan Minyak Menurut Hukum Internasional". Inspirasi. 1 (10). hlm. 139-164.
} 
f. Pencemaran laut yang berasal dari atau melalui udara (UNCLOS 1982, Pasal 212)

Segala upaya sudah dilakukan oleh negara-negara berdaulat guna melindungi kelestarian wilayah lautnya. Tindakan tegas telah dilakukan sesuai dengan ketentuan yang ada, namun tidak menutup kemungkinan untuk terjadinya kecelakaan maupun kelalaian yang mencemari lingkungan. Pada tahun 1948, Konferensi PBB membentuk suatu badan yang terfokus dalam bidang kemaritiman yang bernama International Maritime Organization (IMO). ${ }^{21}$

Dalam perkembangannya, IMO sudah menghasilkan beberapa konvensi yang khusus mengatur polusi dan kompensasi terhadap pencemaran laut oleh minyak yang berasap dari kapal seperti: Maritime Pollution 1978 (MARPOL), International Convention on Civil Liability for Oil Damage 1969 (CLC 1969), dan International Convention on the Establishment of an International Fund For Compensation for Oil Pollution Damage 1971 (Fund Convention 1971). ${ }^{22}$

\section{Prinsip-Prinsip Perlindungan dan Pelestarian Lingkungan Laut}

21 R. P. Kelley. 2011. UNCLOS, but No Cigar: Overcoming Obstacles to the Prosecution of Maritime Piracy". Minnesota Law Review, 95 (6). hlm. 2285-2317.

22 J. L. Suárez-de Vivero. 2013. "The Extended Continental Shelf: A Geographical Perspective of the Implementation of Article 76 of UNCLOS". Ocean \& Coastal Management. 73. hlm. 113-126.
Menurut Philippe Sands di dalam bukunya yang berjudul "Principle of International Environmental Law', definisi hukum lingkungan terkait dengan dua aspek, pertama terkait ruang lingkup subjek hukum dan kompetensi kelembagaannya; kedua, terkait pertanggungjawaban terhadap kerusakan lingkungan. ${ }^{23}$ Deklarasi Stockholm 1972, dalam prinsip ke-2 menyatakan yang dinamakan dengan sumber daya alam di bumi adalah "udara, air, tanah, flora, fauna dan ekosistem alam".

Secara umum menurut Philppe Sands yang pendapatnya dikutip dalam jurnal milik Nadia Nurani Isfarin yang berjudul "Perlindungan Lingkungan Laut Selat Malaka Dari Pencemaran Minyak Lintas Batas", perlindungan dan pelestarian lingkungan laut memiliki beberapa prinsip umum, yaitu:

a. Sovereignity Over Natural Resources and the Responbility not to Cause Damage to the Environment of other States or to Areas Beyond National Jurisdiction

Sebagai prinsip tertua dalam hukum internasional, kedaulatan merupakan karakteristik utama sebuah negara. Menurut John O'Brien dalam buku Melly Aida dan M. Farid Al Rianto yang berjudul Kerjasama Regional Dalam Pengelolaan Dan Perlindungan Lingkungan Laut di Selat Malaka, suatu negara mempunyai kedaulatan internal dan kedaulatan eksternal. Kedaulatan internal berarti

\footnotetext{
23 Isfarin. loc.cit.
} 
negara mempunyai yurisdiksi legislatif, eksekutif dan yudikatif terhadap setiap aktivitas di wilayahnya. Pengakuan kedaulatan terhadap kekayaan alam pertama kali tertuang dalam Resolusi Majelis Umum PBB No. 1803 Tahun 1962 tentang Kedaulatan Permanen terhadap Kekayaan Alam.

\section{Prinsip 21 Deklarasi Stockholm} menyatakan bahwa negaranegara berdasarkan Piagam PBB dan prinsipprinsip hukum internasional, berdaulat untuk mengeksploitasi kekayaan alamnya dan bertanggungjawab untuk menjamin bahwa aktivitas dalam yurisdiksi atau kontrolnya tidak menyebabkan kerusakan lingkungan terhadap negara lain atau terhadap area di luar yurisdiksi nasional suatu negara. Prinsip 21 tersebut diadopsi International Court of Justice dalam Advisory Opinion dalam kasus Legalitas Penggunaan Senjata Nuklir 1996. Berdasarkan prinsip ini, negara memiliki kedaulataan atas wilayahnya serta melaksanakan aktivitas di wilayah teritorialnya. Namun demikian pelaksanaan kedaulatan tersebut tidak boleh melanggar hukum internasional. Prinsip kedaulatan negara terhadap kekayaan alamnya tidak dapat dipisahkan dengan kewajiban negara untuk menjamin tidak merusak lingkungan negara lain dan lingkungan di wilayah yurisdiksinya sendiri.

\section{b. Principle of Preventive Action}

Selain disebutkan dalam Prinsip ke21 Deklarasi Stockholm, prinsip preventive action juga disebutkan dalam Prinsip ke-2 United Nations Conference on Environment and Development (UNCED). Prinsip ini memiliki dua perspektif. Pertama, prinsip ini mewajibkan untuk meminimalisir kerusakan lingkungan sebagai tujuan utama. Kedua, negara berkewajiban untuk mencegah kerusakan lingkungan dalam dan melalui yurisdiksinya, termasuk regulasi, administratif dan tindakan lainnya. Bahkan dalam United States of Foreign Affairs Law, disebutkan bahwa kewajiban negara tidak hanya untuk melakukan tindakan pencegahan, melainkan juga pengurangan dan pengontrolan setiap kerugian lingkungan yang terjadi. Dalam hal pencemaran lintas batas negara, setiap negara diminta untuk melaksanakan dua kewajiban, pertama, untuk melakukan tindakan yang diperlukan dalam itikad baik; kedua untuk mengatur aktivitas publik dan privat yang menjadi subjek dari yurisdiksinya. $^{24}$

\section{c. Cooperation}

Prinsip kerjasama ini bersumber dari prinsip umum good neighbourliness yang dapat ditemukan dalam hukum kebiasaan internasional maupun dalam Pasal 74 Piagam PBB. Prinsip ini terefleksikan dalam beberapa perjanjian internasional

\footnotetext{
24 Melly Aida, et. al. 2015. Kerja Sama Regional Dalam Pengelolaan dan Perlindungan Lingkungan Laut di Selat Malaka. Lampung: Justice Publisher BP FH Unila. hlm. 38
} 
dan didukung oleh praktek-praktek negara utamanya dalam aktivitas yang berbahaya dan darurat. Cooperation tertuang dalam Prinsip ke-24 Deklarasi Stockholm dan Prinsip Ke-27 Deklarasi Rio yang menyatakan bahwa negara-negara harus bekerjasama dalam prinsip good faith dan semangat partnership sebagai upaya perlindungan lingkungan.

\section{d. Sustainable Development}

Prinsip pembangunan berkelanjutan menekankan bahwa pembangunan yang dilaksanakan sekarang tidak boleh mengurangi hak-hak generasi mendatang. Dengan kata lain, pembangunan yang dilaksanakan harus memperhatikan kemampuan lingkungan dalam pemenuhan kebutuhan generasi yang akan datang. Prinsip sustainable mempunyai beberapa aspek, yaitu :25

1) The need to take into consideration the needs of present and future generation;

2) The acceptance on environmenat protection grounds, of limit placed upon the use and exploitation of natural resources;

3) The role of equitable principles in the allocation of rights and obligation;

4) The need to integrate all aspects of environment and the development;

25 Rehulina, et. al. 2015. Ganti Rugi Terhadap Tumpahan Minyak di Laut Menurut Konvensi Hukum Laut 1982 Dihubungkan dengan International Convention on Civil Liability for Oil Damage 1969. Lampung: Justice Publisher BP FH Unila.
5) The need to interpret and apply rules of international law in an integrated and systemic manner.

\section{e. Precutionary Principle}

Prinsip ini menyatakan bahwa tidak adanya temuan atau pembuktian ilmiah yang konklusif dan pasti, tidak dapat dijadikan alasan untuk menunda upayaupaya mencegah kerusakan lingkungan. Sebagaimana dinyatakan dalam Prinsip ke-15 Deklarasi Rio "where there are threats of serious or irreversible damage, lack of full scientific certainly shall not be used asa a reason for postponing costeffective measures to prevent environmental degradation".

\section{f. Polluter Pays Principle}

Organization for Economic Cooperation and Development (OECD) merumuskan polluter pays principle dalam environmental principles and concepts sebagai: "The principle to be used for allocating costs of pollution prevention and control measures to encourage rational use of scarce environmental resource and to avoid distortions in international trade and investment is so called polluter pays principle. That principle means that that polluter should bear the expenses of caring out the above mentioned measures decided by the public authorities to ensure that the environment is in a acceptable states. In other world the cost of these measures should be reflected in the cost of goods and services which cause pollution in production and/or 
consumption. Such measures should not be accompanied by subsidies that would create significant distortions in international trade and investment".

Jadi, polluter pays principle merupakan instrumen ekonomi yang dimaksudkan sebagai mekanisme pembiayaan lingkungan melalui pengenaan pajak, retribusi, pungutanpungutan terhadap hasil limbah dengan harapan adanya keberlangsungan kegiatan ekonomi, perlindungan masyarakat dan lingkungan. Prinsip ini juga dimaksudkan untuk melakukan pengalokasian biaya bagi kegiatan pemulihan lingkungan sehingga tidak dibebankan kepada masyarakat yang tidak mendapatkan manfaat langsung dari suatu aktivitas ekonomi dan adanya pengurangan beban negara dalam membiayai pencemaran lingkungan sebagai akibat kegiatan ekonomi

\section{g. Principle of Common but Differentiated Responsibility}

Prinsip ini dikembangkan dari prinsip kesetaraan dalam hukum internasional dan pengakuan perlakuan khusus bagi negara berkembang. Dalam Pasal 7 Deklarasi Rio dinyatakan bahwa negaranegara mempunyai kewajiban yang sama untuk bekerjasama dalam mengkonservasi, melindungi dan memulihkan ekosistem bumi dengan tetap memperhatikan kontribusi yang berbeda bagi negara maju dan negara berkembang. Perlindungan lingkungan laut dalam kerangka hukum internasional sebenarnya merupakan akumulasi dari The Principle of National Sovereignity and The Freedom of High Sea. International Maritime Organization (IMO) menyatakan bahwa "a right on the part of a astate threatened with the environmental injury from sources beyond its territorial jurisdiction, at least where those sources are located on the high seas, to take reasonable action to prevent or abate that injury".

\section{Perlindungan dan Pelestarian Lingkungan Laut dalam UNCLOS 1982}

Perlindungan lingkungan laut sangatlah berkaitan erat dengan masalah lingkungan hidup pada umumnya dan lingkungan hidup di laut khususnya pada sesuatu yang berkenaan dengan Kawasan. Pasal 145 Konvensi Hukum Laut PBB mengamanatkan kepada setiap otorita untuk mengambil tindakantindakan yang perlu berkenaan dengan kegiatan-kegiatan di Kawasan berdasarkan Konvensi demi terjaminnya perlindungan lingkungan laut yang efektif dari segala tindakan yang merugikan. ${ }^{26}$

Konvensi Hukum Laut PBB 1982 Pasal 145 menyatakan bahwa untuk maksud tersebut, otorita harus membuat dan menetapkan peraturanperaturan, ketentuan-ketentuan, dan prosedur-

\footnotetext{
26 Parthiana. op. cit. hlm. 226
} 
prosedur yang sesuai, antara lain sebagai berikut:

a. Pencegahan, pengurangan, dan pengendalian pencemaran dan bahaya-bahaya lainnya terhadap lingkungan laut termasuk garis pantai dan gangguan terhadap keseimbangan ekologi laut, dengan memerhatikan secara khusus akibatakibat negatif dari kegiatan kegiatan di kawasan, seperti pengeboran, pengerukan, penggalian, pembuangan limbah, pembangunan, dan pengoperasian atau pemeliharaan instalasi-instalasi pipapipa saluran, dan peralatan lainnya yang berkaitan dengan semua kegiatan itu;

b. Perlindungan dan konservasi atas sumber daya atau kekayaankekayaan dari kawasan serta pencegahan atas kerusakan flora dan fauna lingkungan laut.

Melihat dari potensi pencemaran yang terjadi, banyaknya kapal yang melintas dan mengalami kecelakaan sehingga terjadi tumpahnya minyak kelaut yang menjadikan perhatian khusus terhadap perlindungan dan pelestarian lingkungan laut. Tidak terlepas dari perhatian hukum internasional yaitu pada UNCLOS 1982 yang mengatur tentang penyelesaian sengketa dan perlindungan lingkungan laut. Sehingga negaranegara harus mengambil segala tindakan yang perlu sesuai dengan ketentuan yang ada dalam konvensi baik secara individual maupun bersama-sama dalam implikasinya untuk mengurangi dan mengendalikan pencemaran lingkungan laut yang disebabkan oleh segala sumber. Penegasan lebih lanjut tentang jenis apa aja pencemaran lingkungan yang ada terdapat pada Pasal 194 ayat 3 UNCLOS 1982 yaitu:
a. Dilepaskannya
bahan-bahan beracun, berbahaya atau menganggu;
b. Pencemaran dari kendaraan air;
c. Pencemaran dari instalasi dan alat peralatan yang digunakan dalam eksploitasi kekayaan alam dasar laut;

d. Pencemaran dari lain-lain instalasi dan peralatan yang dioperasikan dalam laut

Selanjutnya, UNCLOS 1982 dalam Pasal 192 menegaskan bahwa setiap negara mempunyai kewajiban untuk melindungi dan melestarikan lingkungan lautnya. Kemudian dalam Pasal 193 menegaskan tentang pemberian hak kedaulatan kepada negara untuk mengeksploitasi kekayaan alamnya dan juga, negara-negara mempunyai hak kedaulatan untuk mengeksploitasi kekayaan alam mereka serasi dengan kebijaksanaan lingkungan mereka serta sesuai pula dengan kewajiban mereka untuk melindungi dan melestarikan lingkungan laut. Oleh karena itu, Konvensi Hukum Laut PBB ini mewajibkan kepada 
setiap negara untuk mencegah, mengurangi, dan mengendalikan pencemaran lingkungan laut.

Beberapa hasil analisis terkait aspek penting mengenai perlindungan dan pelestarian lingkungan laut yang diatur dalam Bab XII UNCLOS 1982, yakni:

a. Pencemaran Lingkungan Laut

Pasal 194 menyatakan bahwa negara-negara harus mengambil segala tindakan yang diperlukan untuk mencegah, mengurangi, dan mengendalikan penemaran lingkungan laut dari sumber apapun. Pasal 195 menyatakan dalam mengambil tindakantindakan pencegahan, pengurangan dan mengendalikan pencemaran tersebut, setiap negara harus melakukannya dengan sedemikian rupa agar tidak memindahkan kerusakan atau bahaya tersebut dari suatu daerah ke daerah lain, atau mengubah dari suatu jenis pencemaran ke pencemaran lain. Kemudian dalam Pasal 196 memberikan kewajiban kepada setiap negara untuk mengambil segala tindakan guna mencegah, mengurangi dan mengendalikan pencemaran lingkungan laut yang diakibatkan oleh penggunaan teknologi di bawah yurisdiksi atau pengawasannya. Selanjutnya Pasal 204 menerangkan bahwa hal tersebut dapat dilakukan misalnya dengan cara mengatur, menilai, dan menganalisa berdasarkan metode ilmiah mengenai resiko atau akibat pencemaran lingkungan laut.

b. Upaya Perlindungan dan Pelestarikan Lingkungan Laut

Pasal 197 - 201 UNCLOS 1982 memberikan kewajiban kepada setiap negara untuk melakukan kerjasama baik regional maupun global dalam upaya melindungi dan melestarikan lingkungan laut. Sebagaimana ditegaskan dalam pasal tersebut kerja sama dapat berupa pemberitahuan ada pencemaran lingkungan laut, penanggulangan bersama bahaya atas terjadinya pencemaran laut, pembentukan penanggulangan darurat, kajian, program-program riset, pertukaran informasi dan data serta membuat kriteria ilmiah untuk mengatur prosedur dan praktik bagi pencegahan, pengurangan, dan pengendalian pencemaran lingkungan laut.

\section{c. Bantuan Teknis}

Pasal 202 menentukan bahwa negara-negara maju memiliki kewajiban untuk memberikan bantuan secara teknis kepada negara berkembang dalam rangka upaya perlindungan dan pelestarian lingkungan laut. Kemudian Pasal 203 menerangkan bahwa untuk tujuan pencegahan, pengurangan dan pengendalian lingkungan laut, negaranegara berkembang harus diberikan perlakuan khusus oleh organisasiorganisasi internasional dalam alokasi dana dan bantuan teknis beserta pemanfaatannya. 
d. Pengaturan dan Penegakkan Hukum Nasional

Konvensi Hukum Laut PBB mewajibkan setiap negara untuk membuat aturan perundang-undangan mengenai pencegahan dan pengendalian pencemaran terhadap lingkungan laut dari segala sumber, seperti pencemaran yang berasal dari sumber daratan, dari kegiatan-kegiatan yang tunduk pada yurisdiksi nasional, pencemaran yang berasal dari kegiatan-kegiatan di Kawasan, pencemaran yang dikarenakan oleh dumping, pencemaran yang berasal dari kendaraan air, dan juga pencemaran yang berasal dari atau melalui udara. Ketentuan ini dimuat dalam Pasal 207 212.

\section{e. Tanggung Jawab dan Ganti Rugi}

Setiap negara bertanggung jawab atas pemenuhan kewajiban yang bersangkutan dengan perlindungan dan pelestarian lingkungan laut. Selain itu, negara juga harus menjamin adanya sistem perundang-undangan terkait dengan cara memperoleh ganti rugi yang berhubungan dengan kerusakan yang terjadi. Ketentuanketentuan yang mengenai hal tersebut dimuat dalam Pasal 235 tentang Tanggung Jawab dan Kewajiban Ganti Rugi, yang menyatakan bahwa negara-negara bertanggung jawab untuk pemenuhan kewajiban-kewajiban yang terkait dengan perlindungan dan pelestarian lingkungan laut, selain itu negara-negara juga harus menjamin tersedianya upaya untuk menuntut sistem perundangundangan untuk diperolehnya ganti rugi tersebut, dan untuk menjamin ganti rugi yang segera setiap negara harus bekerjasama dalam melaksanakan hukum internasional yang berlaku demi perkembangan hukum internasional berkenaan dengan tanggung jawab dan kewajiban ganti rugi serta penyelesaian sengketa yang timbul.

\section{f. Klasifikasi Tentang Kekebalan}

Ketentuan-ketentuan mengenai perlindungan dan pelestarian lingkungan laut yang termuat dalam Konvensi Hukum Laut PBB 1982 tidak berlaku bagi kapal perang, kapal bantuan, dan lain-lain namun pengoprasiannya harus sesuai. Selain itu, Konvensi ini juga turut menegaskan bahwa setiap kewajibankewajiban khusus yang diterima setiap negara berdasarkan konvensi khusus yang berkaitan dnegan perlindungan dan pelestarian lingkungan laut harus tetap dilaksanakan dengan konsisten sebagaimana diatur dalam Pasal 236 237.

Jadi, sesungguhnya Hukum Laut PBB 1982 sudah sangat jelas menerangkan mengenai ketentuanketentuan terkait dengan upaya pencegahan, pengurangan, dan pengendalian pencemaran seperti pengaturan dan penegakkan hukum nasional sampai dengan tanggung jawab dan ganti rugi, dan bahaya-bahaya lainya terhadap lingkungan laut. Hukum Laut 
PBB 1982 juga memberikan himbauan kepada negara-negara untuk memberikan bantuan secara teknis dalam rangka perlindungan lingkungan laut.

Negara-negara dalam wadah organisasi internasional mempunyai peranan penting pula dalam pelestarian lingkungan laut. Organisasi internasional global dan regional dapat membentuk suatu perjanjian yang mengatur tentang ketentuan, standar, dan praktek secara internasional menjadi sebuah prosedur yang bertujuan untuk melakukan perlindungan dan pelestarian lingkungan laut, namun tidak melupakan aspek kekhususan dari daerah regional tentang pembentukan kebijakan dan pengaturan dari perlindungan dan pelestarian lingkungan laut itu sendiri. Contohnya seperti Indonesia, Malaysia dan Singapura sebagai negara yang berbatasan langsung dengan Selat Malaka sesuai dengan Pasal 197 UNCLOS 1982 negara-negara memiliki kewajiban untuk membentuk kerjasama dalam pengelolaan dan perlindungan lingkungan laut.

Organisasi internasional melalui negara-negara harus melakukan tindakan pencegahan dan penanggulangan secara terlebih dahulu terhadap lingkungan lautnya dan memberitahukan apabila ada suatu keadaan urgent akibat dari pencemaran kepada negara-negara dan organisasi internasional lain. Pencemaran yang terjadi pada negara yang terkena diharuskan bekerja sama dengan organisasi internasional yang berkompeten dalam menanggulangi pencemaran lingkungan laut. Organisasi internasional berperan penting dalam melakukan pengkajian, dan penyelenggaraan program riset untuk mencegah dan menanggulangi pencemaran lingkungan laut yang terjadi.

\section{PENUTUP}

Perlindungan dan pelestarian lingkungan laut mendapatkan perhatian serius oleh hukum internasional, terutama melalui pengaturan melalui UNCLOS 1982. Dalam Pasal 192 konvensi ini menegaskan bahwa setiap negara mempunyai kewajiban untuk melindungi dan melestarikan lingkungan lautnya. Kewajiban ini kemudian disusul dengan pemberian hak kepada negara atas pengelolaan sumber daya alamnya di laut (Pasal 193). Karena itulah, konvensi ini mewajibkan setiap negara untuk mencegah (prevent), mengurangi (reduce), dan mengendalikan (control) pencemaran lingkungan laut yang terjadi di wilayahnya. Pendekatan dasar konvensi terhadap pencemaran laut diletakkan dalam Pasal 194-196. Dalam Pasal 194 menyatakan bahwa negara-negara harus mengambil segala tindakan yang diperlukan untuk mencegah, mengurangi, dan mengendalikan pencemaran lingkungan laut dari sumber apapun.

Dalam mengambil tindakan-tindakan pencegahan, pengurangan dan mengendalikan pencemaran tersebut, 
setiap negara harus melakukannya dengan sedemikian rupa agar tidak memindahkan kerusakan atau bahaya tersebut dari suatu daerah ke daerah lain, atau mengubahnya dari suatu jenis pencemaran ke pencemaran lain. Kemudian Pasal 196 Konvensi ini memberikan kewajiban kepada setiap negara untuk mengambil segala tindakan guna mencegah, mengurangi dan mengendalikan pencemaran lingkungan laut yang diakibatkan oleh penggunaan teknologi di bawah yurisdiksi atau pengawasannya. Hal tersebut dapat dilakukan misalnya dengan cara mengatur, menilai, dan menganalisa berdasarkan metode ilmiah mengenai resiko atau akibat pencemaran lingkungan laut.

UNCLOS 1982 menentukan bahwa negara-negara maju memiliki kewajiban untuk memberikan bantuan secara teknis kepada negara berkembang dalam rangka perlindungan dan pelestarian lingkungan laut. Bantuan teknis tersebut dapat berupa pelatihan tenaga teknis dan ilmiah, partisipasi dalam program-program internasional, bantuan peralatan, pelatihan pembuatan pralatanperalatan yang diperlukan, dan pengembangan riset, monitoring, pendidikan, dan programprogram lainnya. Untuk tujuan pencegahan, pengurangan, dan pengendalian lingkungan laut, negaranegara berkembang harus diberikan perlakuan khusus oleh organisasi- organisasi internasional dalam alokasi dana dan bantuan teknis beserta pemanfaatannya.

\section{Bibliografi}

\section{Buku:}

Aida, Melly. et. al. 2015. Kerja Sama Regional Dalam Pengelolaan dan Perlindungan Lingkungan Laut di Selat Malaka. Lampung: Justice Publisher BP FH Unila.

Diantha, I Made Pasek. 2017. Metodologi Penelitian Hukum Normatif Dalam Justifikasi Teori Hukum. Jakarta: Prenada Media Group.

Hong, Nong. 2012. UNCLOS and Ocean Dispute Settlement: Law and Politics in the South China Sea. London \& New York: Routledge.

Kusumaatmadja, Mochtar. 1986. Hukum Laut Internasional. Bandung: Binacipta.

Parthiana, I Wayan. 2014. Hukum Laut Internasional dan Hukum Laut Indonesia. Bandung: Yrama Widya.

Prodjodikoro, Wirjono. 1984. Hukum Laut Bagi Indonesia.Bandung: Sumur Bandung.

Rehulina, et. al. 2015. Ganti Rugi Terhadap Tumpahan Minyak di Laut Menurut Konvensi Hukum Laut 1982 Dihubungkan dengan International Convention on Civil Liability for Oil Damage 1969. Lampung: Justice Publisher BP FH Unila.

Sodik, Dikdik Mohammad. 2011. Hukum Laut Internasional dan 
Pengaturannya di Indonesia.

Bandung: Refika Aditama

\section{Jurnal:}

Agoes, E. R. 2004. "Praktik NegaraNegara Atas Konsepsi Negara Kepulauan". Indonesian Journal of International Law. 1 (3). hlm. 441464.

Amir, Usmawadi. 2013. "Penegakan Hukum IUU Fishing Menurut UNCLOS 1982 (Studi Kasus: Volga Case)". Jurnal Opinio Juris, 12. 6892.

Ereli, E. 1966. "Submerged Lands Act and the Geneva Convention on the Territorial Sea and the Contiguous Zone". Tulane Law Review. 41. 555.

Isfarin, Nadia Nurani. 2012. "Perlindungan Lingkungan Laut Selat Malaka Dari Pencemaran Minyak Lintas Batas". Jurnal IImu Hukum. 15 (2). 206-224.

Kelley, R. P. 2011. UNCLOS, but No Cigar: Overcoming Obstacles to the Prosecution of Maritime Piracy". Minnesota Law Review, 95 (6). 2285-2317.

$\mathrm{Ku}$, Charlotte. 1990. "The Concept of Res Communis in International Law". History of European Ideas, 12 (4). 459-477.

Laffoley, D. \& Freestone, D. 2017. "A World of Difference-Opportunities for Applying the 1972 World Heritage Convention to the High Seas". Aquatic Conservation: Marine and Freshwater Ecosystems, 27. 7888.

Lasabuda, Ridwan. 2013. "Pembangunan Wilayah Pesisir dan Lautan dalam Perspektif Negara Kepulauan Republik Indonesia". Jurnal IImiah Platax. 1 (2). 92-101.

McDorman, T. L. 2012. "The Continental Shelf Regime in the Law of the Sea Convention: A Reflection on the First Thirty Years". The International Journal of Marine and Coastal Law. 27 (4). 743-751.

Ningsih, N.K., Indra, M. \& Edorita, W. 2016. "Pertanggungjawaban Negara Terhadap Pencemaran Laut Timor Oleh Tumpahan Minyak Australia Berdasarkan UNCLOS III 1982 dan Hukum Lingkungan Internasional". Jurnal Online Mahasiswa, 3 (1). 1-15.

Ruddy, F.S. 1968. "Res Nullius and Occupation in Roman and International Law". University of Missoury (Kansas City) Law Review. 36. 274-282.

Sjawie, Hasbullah F. 1999. "Konsep Negara Kepulauan pada Konferensi Hukum Laut Tahun 1958 dan Tahun 1960". Jurnal Hukum dan Pembangunan, 29 (2). 131-143.

Soemarmi, A., Indarti, E., Pujiyono, \& Diamantina, A. 2019. "Konsep Negara Kepulauan dalam Upaya Perlindungan Wilayah Pengelolaan 
Tanjungpura Law Journal $\mathbf{\square}$ Vol. 4, Issue 2, July 2020

Perikanan Indonesia". Masalah-

Masalah Hukum. 48 (3). 241-248.

Sofyan, Ahmad. 2010. "Tanggung Jawab dalam Pencemaran Laut yang Disebabkan Minyak Menurut Hukum Internasional". Înspirasi. 1 (10).139164.

Suárez-de Vivero, J. L. 2013. "The Extended Continental Shelf: A Geographical Perspective of the Implementation of Article 76 of UNCLOS". Ocean \& Coastal Management. 73. 113-126. 